\title{
Stipulation in the International Commercial Contracts
}

\author{
Ali Honari Tehrani ${ }^{1}$ \\ ${ }^{1}$ Is lamic A zad university of Bushehr, Iran \\ Correspondence: Ali Honari Tehrani, Is la mic A zad university of Bushehr, Iran.
}

Received: January 30, 2016

Accepted: February 20, 2016 On line Published: July 31, 2016

doi:10.5539/jpl.v9n6p75

URL: http://d x.doi.org/10.5539/jpl.v9n6p75

\begin{abstract}
According to the principle of will power or will dominance and the principle of freedom to contract which have been manifested in the article nu mber ten of the civil code the will power of individuals dominates the regulations of closing a contract and its after effects and the freedom of will power here has gained the acceptance as a principle. By closing a contract by two free wills that contract becomes binding and according to the binding principle or provision in contracts the sides of a contract will be committed to carry out the terms and content which is inserted in a contract unless it becomes terminated with by the volition of the sides of the contract themselves or due to a legal cause. Since according to the principle of freedom to contract its sides can shun from closing any contract which is an obvious violation of law, due to the same reason they can also take into consideration any condition or term which isn't an obvious violation of law and according to the principle of binding ness of contracts the sides of them and their vicars are bound to execute the conditions which are stated in it. One of the conditions of contracts which can be considered is the condition of stipulation .

In the present study in addition to scratch the surface on the subject of stipulation in contracts it is expected that the theoretical as pect of the essence of stipulation gets evident, the view point of Islamic jurisprudence and the legal proceedings become stated and the is sue that stipulation is claimable under what conditions and in what manner. By carry out a comparative study we get aware of the views in several legal systems toward stipulation and also its position in the private international law and the latest changes in the domain of stipulation specifically ones which are presented at the international level.
\end{abstract}

Keywor ds : stipulation, international commercial contracts, comparative law, conflict of laws

\section{Introduction}

One of the general principles in law is the principle of keeping the promise or pactasuntservanda which is known to the whole legal systems in the world. According to this principle anyone is responsible and bound to carry out the affair that is committed to do it and put it into practice and/or shun from doing anything which was committed to quit it. The violator of the mentioned principle is committed to compens ate for the loss and damage out of doing or quit doing an action. According to the article number two hundred and twenty one of the civil code of Iran: "If anyone promises or undertakes to do something or undertakes to shun from doing something in case of violation $\mathrm{s} /$ he is responsible for any harm which is occurred to the other side of the contracts',

\subsection{Review of Literature}

1) The essay titled as 'Regulation of stipulation in the Law of Iran by Akbar BarzegarSamghabadi .

2) The essay titled as "Position of stipulation in contracts by Dr. A mir Housseinabadi. In this essay the author totally is protests against the position and the significance of the stipulation in contracts and doesn't get into discussing about the difference of this position in the internal and the international legal system.

3) The essay titled as "the role of UNCITRAL or the United Nations Commission on International Trade Law.

\subsection{Research Goals}

1) By considering various aspects of stipulation and stating the significance of this affair in a contract specifically contracts which have a transnational element, these aspects aid the legal and natural persons as the beneficiaries of an international commercial contract to determine a proper stipulation. 
2) By presenting the views and opin ions of legal experts in this domain we are going to present some approaches in order to standardize the way of dealing with and deducing stipulation in commercial contracts at the international level.

3) By doing a comparative study of stipulation and contrasting various legal views from a scientific angle on stipulation in a contract compile an appropriate scientific-legal collection until sin similar situations the university students and researchers can be able to refer to it as a proper guide and source.

\subsection{Research Questions}

1) What is the entity of Stipulation?

2) Does this stipulation in case of any violation of contract on behalf of the committed side is completely claimable or not?

3) Does the obligee essentially forced to prove the occurrence of the damage or harm to him/herself to be considered as deserved to receive compensation from obliger or the mere existence of the condition of paying the stipulation and accepting it from obliger is sufficient to oblige him/her to compensate for the harm or loss?

\subsection{Research Hypotheses}

1) Ths issue that whether the stipulation to punish the violator for shun from performing his/her commitment is a kind of civil penalty which is being determined for him/her or the subject that this price is to compensate for the harm which is occurred to the obligee due to the violation of commitment deserves discussion and deliberation but for the time being in the law of Iran legal experts consider the essence of stipulation as a harm; that is the harm which has been determined in advance by the mutual consent of the sides of the contract and it is considered as a kind of harm for the non-performance of a job which the two sides have reached an agreement on the amount of it. The article number two hundred and thirty approves of this story .

2) It seems that in case the damage which is occurred is more than the determined rate which is inserted as the requirement or condition claiming for a surplus cost is impossible but in cases in which the damage is less than the determined rate which is inserted in the condition we can content ourselves with this rate.

3) One of the specific cases which exists in this legalestablishment is that the obliger can't shun fro m paying the accepted rate in the contract on the pretext that due to his/her breaking of the promise no harm goes for the oblige.

\section{Stipulation from the Viewpoint of Comparative Law}

Comparative law is a collection of rules and regulations which are not relevant to a specific relation but it is a science which scrutinizes and analyzes the legal questions and problems from a comparative view point.

In recent years paying attention to comparative law for resolving the existing requirements at the international level specifically in the area of economic and commercial fields has augmented emin ently. At the international level for preparing and drawing up the international conventions, sample codes, and the conventional contracts widespread comparative studies have been carried out from regional and international organizations and institutes or is in the process of execution. At the national level countries have attached lots of significance to comparative studies for correcting the existing regulations and the ratification of new codes. Nowadays comparative law is not only fruitful but is also necessary. Comparative law is among the legal discussions which more or less studies and scrutinizes the law in its totality. Subjects such as what is sues the law is pursuing for or that the legal codes of the country have undergone what changes and evolutions.

\subsection{Standardize and Orchestrate the Rules and Regulations}

Standardizing and orchestrating regulations and rules may be done through several ways. This process may be carried out at the national level through correcting the existing regulations or enacting new codes at the international level through conclusion of international conventions and contracts and/or through voluntary admission of some regulations on behalf of merchants, firms, and institutes.

\subsection{Stipulation from the Viewpoint of Foreign Legal Systems}

Studying the key legal systems all over the world indicates that the behavior of legislators and magistrates in several states toward stipulation isn't the same. The reas on for it should be looked for in the existence of various and variable general policies of the states in relation to commercial contracts. These policies are variable for this reason that any state expresses a reaction which is proportionate to sits requirements and different from other states toward stipulation and this is variable on the grounds that in any state at any period in history stipulation hasn't been behaved equally. 


\subsection{Stipulation in the English Common Law}

Specification of the legal entity of stipulation in the English Common Law is of considerable significance in stating to put a law into force or the cancellation of it. Th is specification of course rests with the judge until state by studying the conditions of the obligee that whether the sides of a contract are committed to execute it or not.

From traditional point of view the English judge any time which sees a condition in which it is stipulated that in case one side of a contract doesn't fulfill $\mathrm{h}$ is/her commitment he/she is obliged to pay a definite price to the other side. At first this question arises that whether the intention of the two sides to insert the condition is to determine a fine for the violator side or the sides of the contract have chosen the condition as a tool for determining the exact amount of the probable damage by the oblige? Giving effect to or turn down the condition by the contentious depends on the discernment and wisdom of the judge. This type of encounter by an English judge has roots in history and goes back to the traditional disputes and jealousies among courts of justice and the common law. The relevant account is that in the past the common law courts according to the principle of freedom of contracts respected any condition for paying the stipulation and shunned from manipulating its compound. This behavior was exactly contrary to the behavior of the courts of justice which in some contracts which their subject was cash declared the condition as null And void according to which the debtor committed to pay an amount which was by far more than the defin ite a mount of debt in case of non-payment of the exact cost of debt and its interest on the due date. In fact the courts of justice wherever encountered with the fraud of creditors in such contracts and/or viewed the delay of the debtor in repaying the debt not as his/her fault or defect didn't fulfilled the condition of paying the stipulation which was inserted in the contract but they themselves determine the amount of the real damage and sentenced the oblige to pay for it. This kind of practice in the courts of justice was for a perio $d$ in practice just concerning the commit ments which their subject was paying an amount of money; but, little by little this practice was performed for commitments which their subjects were doing or quit doing an action of another kind. Later on in the eighteenth century any kind of condition which was determined on paying the stipulation in case it didn't have any correcting force or effect sand/or wasn't irrational was declared false or null and void .

\subsection{Stipulation in the Law of France}

The root of the law of France in this subject should be looked for in the law of the ancient Rome and the Christian law. In the law of the ancient Rome stipulation was merely aimed for punishing or correcting the obligee. Commitment of the debtor was inserted in the form of a condition according to which anytime the debtor didn't fulfill his/her co mmit ments/he should pay a price as a fine. Th is condition which was known as "stipulatiopoenae" was used in fact in cases in which obliging the obligor to fulfill his/her commitments was impossible by this explanation that by co mmitting the obligor to pay an a mount of cash as the princip le co mmit ment the obligee could force him/her to fulfill the intended commit ment. The condition was written from obligee's mouth or viewpoint as follows in the statement: "If you alienate the such and such article to me do you promise to pay the such and such money to me?" The concept of the condition was in fact this one, "the obligor should pay such and such money." And this was the principal commit ment not the commit ment of the debtor. Another commit ment (i.e. alienation of the ownership of an artic le) was impossible to give effect to and was just inserted in the contract as the condition for paying the fine to the obligee.

These two-dimensional features of stipulation were later pursued in the Christion law of the Middle Ages. Exploitation of stipulation was in fact an instrument for escaping from religious codes which viewed the usury as a prohibition; that is instead of determining a percent as interest and/or the retaliation for delaying it was inserted in the contract that anytime that the obliger didn't pay his/her debt on time they should pay such and such money for this delay and the oblige directly brought a lawsuit against them to retake the determined cash as stipulation.

\subsection{Stipulation in the Law of Germany}

Contrary to the French legislator the German leg islator from the very beginning of formu lation or codification of the civil code (B.G.B.) accepted the two theories of "Du Moulin" and "Poitiers" according to which stipulation is changeable. Despite this, in Germany stipulation doesn't just bear the concept of determining the damage but in addition to this has a corrective aspect and for forcing the obligor to fulfill his/her commit ment is used. (i.e. artic le number 420 of civil code) On the other hand the legal system of Germany contrary to the Common Law doesn't dis sociate the corrective stipulation and the obligational aspect which has the function of determining the exact amount of damage; that is in both cases the obligational aspect is capable of putting into force or enforceable .

But while the German legislator hasn't shown any leniency toward stipulation the legal proceedings in this state have always attempted to restrict the users' freedom to make use of it.

The main regulations on stipulation should be looked for in the articles number three hundred and forty and three 
hundred and forty three of the civil code of Germany. Article number three hundred and forty permits the creditor or obligee to bring a lawsuit against the debtor or obligor until any time which the stipulation fee wasn't sufficient to compensate for the real damage to the obligee s/he become able to claim for this surplus cash on the determined cash on condition that for the surplus cash according to the general law put forward reason or adduce. Despite this, as it is applicable to the French law German Law doesn't allow the oblige to both ask for the payment of the stipulation and simultaneously ask for executing the principal commitment unless in cases in which stipulation is being determined to compensate for any delay in fu lfilling the arranged commitment. (Article 341).

\subsection{Stipulation in the Law of the Former Soviet Socialist Republic}

In the legal system of the Former Soviet Socialist Republic like German system stipulation has also a corrective aspect and had also been used for forcing the obligor to fulfill his/her commitments and also had the aspect of determining the fixed damage (compensation) rate. This sense can be deduced fro $m$ the a malgamation of the civil code regulation which was ratified in 1992 and the code of December 19th, 1933 in the Former Soviet Socialist Republic on stipulation. According to the article one hundred and forty one of the civil code stipulation consists in a condition according to which one side of a contract gets committed that "In case of lack of fulfillment of the commitment and/or delay in performing it pay an a mount of money to the other side as his/her possession." In such a case the obligee will be rightful until by his/her choice receive the damage which is due to non -performance of the commitment or the stipulation fees and anytime that the determined cash is determined to compensate for the damage of delay ing in fulfillment of the commitment and/or incomplete fulfillment of the commit ment the oblige can claim the stipulation aside from executing the principal co mmitment or claim for the stipulation and/or in case of the order of law the obligee can both claim the payment of stipulation and also claim the real damage.

\subsection{Stipulation in the Law of Iran}

In order to study the stipulation in the law of Iran we should clearly make a difference between the case in which the subject of main commitment is an amount of money and the case in which the debtor is committed to fulfill a non-monetary commitment. Doubts which arose on stipulation in the first type of trades after the Islamic Revolution necessitate this separation.

\subsubsection{Stipulation on Cash}

In Iran prior to The Isla mic Revolution the sides of a contract could in cases which the subject was the principal commitment to pay and/or retaking an amount of cash similar to what was popular for the cash case reach an agreement which in case of delay in pay ment the debtor is obliged to pay an amount as stipulation to the creditor. Despite this, the mentioned cash couldn't violate or exceed the legal interest and each time the determined stipulation exceeded the legal interest the court investigated it and/or the registrar was obliged to reduce the rate of stipulation to the extent of the mentioned interest rate. On the contrary, in case the stipulation between the sides of a contract was less than the arranged legal interest rate the obligee was only rightful to claim the stipulation and nothing more than that.

\subsubsection{Stipulation on Non-Cash}

From the view point of Islamic jurisprudence inserting the stipulation in a contract has no religious prohibition. From the viewpoint of Iran's statute the insertion of stipulation in contracts is faultless. The principal article on stipulation is the article nu mber two hundred and thirty of the civil code of Iran which is similar to the article one thousands, one hundred and fifty two of the civil code of France which states: "In case be sides the trade sit was conditioned that in case of violation the violator should pay a price as damage the judge can't sentence him/her to a payment which is more or less than the determined rate'.

In this manner the legislator in Iran considers the stipulation as determining the fixed damage rate as it was stated in the theories of "Poiters" and "Du Moulin" and also this is popular in France. The result of this feature of stipulation in the law of Iran is that its price is unchangeable. Predicting the stipulation in the international commercial contracts is usually being performed in two ways. At times the stipulation is for compensating for the damage which is due to the non-performance of a commit ment whether a monetary or non-monetary ones; in this case stipulation sis being stated in the contract in the form of a de fin ite a mount of money and/or a percentage of the price of an article and the service which are the subject of that contract. Occasionally the stipulation is predicted in order to compens ate for the damage which is due to the non-adaptation of what the obligor has executed with what is up to him/her due to the contract. In case of the occurrence of the last item the stipulation will be determined in the form of a percentage of the price of the contract and its rate is variable depending on the kind and significance of the fault. Determining the rate or amount of stipulation in case of violation is being predicted by means of specific mathematical equations which are predicted in the contract in a way that in addition that a fair 
compensation will be plausible for the obligee the payable rate as the price of damage won't exceed a definite payment cap although a damage which is more than the predicted amount affect the oblige .

\subsection{Stipulation and the System of Conflicting Laws}

In terms of accuracy of stipulation it is impossible to hold a unitary national rule or code as efficient to be accountable and as we will see it is possible that the determined stipulation become a function of multiple internal codes. This point that the impact of stipulation depends on the accuracy and credit of the principal contract complicates the job as well since to state the accuracy of the stipulation the judge is at first obliged to study the principal commitment of the obligor that himself necessitates the urgency of looking for the ruling code over the recent commitment. This point is not the subject of our discussion and we leave it but concerning the stipulation itself by assuming the achievement of the accuracy of the principal co mmit ment no unitary code is effective.

\section{Conclusion}

Although several vie ws exist concerning stipulation according to the account of this study but what can be stated is that firstly alluding to the principle of will power or will dominance for the sides of a contract in executing the article ten of the civil code and by alluding to the principle of the authenticity of outwards of the words or statements. Secondly, by noting the theory by legal experts by which the law maker commits no error in codify ing the laws and by codifying an statement declares its meaning and aims at its purport and in the contracts the sides of it by stating any statement declare its meaning and by inserting the stipulation in fact intend to show another commit ment except for the principal commit ment which in case of violation of the obligor it will be used against him/her. Thirdly, this study indicates that to what extent stipulation is being kept obscure. This point is specifically correct when stipulation has been used under the frame work of an international contract; A contract which is dependent on an external element and bring the conflicting interests of states and several legal systems against each other. In fact in terms of dissimilarity of the policy of states legal systems concerning the legal effect of stipulation in the private contracts aren't so significantly similar to each other either in terms of the content of the substantive law and either in terms of the systems of conflicting codes which guide the judge in choosing the dominant substantive law on the stipulation. One part of this vagueness originates from this point that in the course of history within each state no unique or coherent procedure has been taken to handle stipulation.

Noting the presented issues in this research to prove the profitability and the necessity of determining the stipulation we can enumerate the following reasons:

1) Frequency and the incessant use of this legal establishment in commercial contracts is the reason for its profitability and necessity. In fact, the privileges of inserting the stipulation in contracts are manifold aside from this point that in terms of procedural law the burden of proof is taken from obligee's shoulder and is put on the obligor's shoulder.

2) The point that although the price of stipulation is changeable in some states by the judge, but the principle is that it is urgent and indispensible in all states.

3) Stipulation is that the debtor is exempted from doing his/her principal commitment except in cases in which the sides of contract set different conditions since in fact stipulation according to its nature is replaced by a price which the obligor in case of violation according to the general princip le of compensation for the damage which is due to the non-performance of commitments should pay.

In this manner stipulation allows the obligor until while closing a contract predict the amount of damages which will be undergone in case of violating the contract and by noting the hazard which any commercial contract guarantees take a logical and sound decision. The obligee will also have an influential tool until s/he can force the oblige to perform his/her commit ment which s/he has taken on.

\section{References}

Admin istration of justice acts. (1996, 1705).

Allameh Helli. (1945). Mokhtalefal-Shiah (Vol. 1). Tehran Publication.

Bahrani, Y. (1405 A.H.). Alhadaek al-Nazerah (Vol. 5). Publication of Qom Seminary. Ebram, A. (1993). Legal entity of written promise. FirdowsiSPublication. 2nd publication .

Emami, A. (1999). Civil code of Iran (Vol. 1). Publication of the Higher Institute of Accounting.

Emami, S. H. (1968). Civil Code (Vol. 1). Eslamieh Book shop.

Federation Council. Former Civil code of the Former soviet Union codified on 1926.

Frankfurt Parliament. National law of Germany or Burgerliches Gesetzbuch articles 420, 343, 340 ratified in 1900. 
Haeri, S. A. (Shah Bagh). (2005). Explanation of the Civil code. Aftab Printing House. Ministry of Justice.

Hazard, S. M. (1969). The Soviet Legal System. New York. Sp. 447.

Heidarian, M. (2003). Preliminaries on the Science of Law. Dadghostar Publication.

Housseini, S. M. R. (2008). Civil Code in the legal procedding. 4th publication. Madjd Publication.

IbnGhoddamah, Wefq al-din. (2013 AH.). Al-Moqanni (2nd ed.). Al-Arabiah Library. Beirut.

Ja'afariLangroudi, Mohammad ja'afar. (1988). Terminology of Law. Ganj-e-Danesh Publication.

JaberiArablu, M. (1983). Persian Islamic Jurisprudence Idioms. A mirkab ir Publication.

Katouzian, N. (1989). The preliminary series of Civil code. Behnashr Publication.

Katouzian, N. (1999, Spring). Analysis and justification of legal proceedings. Dadghostar Publication.

Law v. Red ditch Local Board. (1892).

Mirzae, A. (2005). Code of registration in the present legal system. 1st publication. Behnami Pub lication .

National Consultation Assembly. Former Civil Procedure Code of Iran. ratified in 1939.

OURILAC ETDE MALAFOSSE: DroitRomain EtAncienDro it, Paris, 1961, p.174.

Shahidi, M. (2003). Civil Code: Effects of contracts and commitments (Vol. 3, 1st ed.). Madjd Publication.

Shiravi, A. (2010). Comparative Law (9th ed.). SAMT Publication.

The UN. "Vienna Convention.” (1980). (International purchasing contracts for movable articles .

WEILLET ET TERRE: DROIT Civil, les obligations. 2nd ed. No.461.

Zahedi, A. (2011). A collection of applied legal criminal codes (1st ed.). Javdaneh-jangal Publication.

\section{Copyrights}

Copyright for this article is retained by the author(s), with first publication rights granted to the journal.

This is an open-access article distributed under the terms and conditions of the Creative Commons Attribution license (http://creativecommons.org/licenses/by/4.0/). 